\title{
Microbiological, Physicochemical, and Antioxidant Properties of Plain Yogurt and Soy Yogurt
}

\author{
Sung-Mee Lim \\ Department of Food Nutrition\& Science, Tongmyong University, Busan 608-735, republic of Korea

\section{플레인 요구르트와 소이 요구르트의} \\ 미생물학적, 물리화학적 및 항산화 활성
}

\author{
임성미 \\ 동명대학교 식품영양과학과 \\ (Received October 14, 2013 / Accepted December 3, 2013)
}

\begin{abstract}
This study evaluated the physicochemical and microbiological characteristics and antioxidant properties of yogurt samples fermented with lactic acid bacteria (LAB) obtained from pickled cabbage. API 50 CHL systems and 16S rRNA nucleotide sequence analyses revealed that the isolates were Lactobacillus casei PC05 and L. acidophilus PC16. Cell counts, titratable acidity, and viscosity of the yogurt samples fermented with $L$. acidophilus PC16 were significantly higher than those of the samples fermented with $L$. casei PC05 $(P<0.05)$. The detected cell counts and physicochemical properties were significantly lower in plain yogurt than in soy yogurt $(P<0.05)$. Yogurt samples fermented with $L$. acidophilus PC16 exhibited higher antioxidant activity, measured as ability to scavenge 1,1-diphenyl-2-picrylhydrazyl (DPPH) radicals and chelate ferrous ions, than those fermented with $L$. casei PC05. However, the ability to scavenge superoxide anions and superoxide dismutase (SOD) activity were significantly $(P<0.05)$ higher in yogurt samples fermented with $L$. casei PC05 compared to those in samples fermented with $L$. acidophilus PC16. The antioxidant activity of soy yogurt was significantly $(P<0.05)$ higher than that of plain yogurt. The antioxidant activity of the tested strains resulted in lipid peroxidation inhibition (in vitro), which may be related to the elimination of free radicals, chelating ability, and reducing power. There were no significant differences in the physicochemical properties and antioxidant activities of the yogurt samples during cold storage.
\end{abstract}

Keywords: DPPH and superoxide anion radical scavenging, ferrous ions chelating, plain yogurt, reducing power, soy yogurt

Oxygen is an essential element in aerobic organisms. It oxidizes biomolecules through the generation of reactive oxygen species (ROS) such as singlet oxygen, superoxide anions, and hydroxyl radicals, leading to cell death and tissue injury (Halliwell and Gutteridge, 1984). ROS can be significantly increased by exogenous factors such as cigarette smoke, UV radiation, and food preservatives and by endogenous factors that are generated by metabolic reactions in the human body (Castro and Freeman, 2001). Elevated concentrations of ROS are likely to be a major cause of modifications of cell structures, including lipids, proteins,

*For correspondence. E-mail: limsm020@tu.ac.kr; Tel.: +82-51-6291714; Fax: +82-51-629-1709 nucleic acids, and biological molecules, genetic mutations due to cytotoxic and mutagenic damages of DNA and nucleotides in cells, and the activation of pro-apoptotic factors (Halliwell et al., 1995). As a result, oxidative stress by ROS plays a significant pathological role in a wide range of age-related degenerative and chronic diseases. These include cardiovascular and inflammatory bowel diseases, emphysema, cirrhosis, arthritis, diabetes, neurodegeneration, immunologic disorders, and cancer (Castro and Freeman, 2001).

To avoid cellular damage by ROS, almost all organisms have their own defense and repair mechanisms based on antioxidant enzymes as well as non-enzymatic antioxidant compounds. However, these mechanisms are not sufficiently effective to completely prevent damage; therefore, exogenous 
antioxidants are necessary that can delay or prevent oxidative damage by scavenging free radicals and ROS or active detoxifying proteins (Li et al., 2012).

There is increasing interest in elucidating the antioxidant defense mechanisms of the host with regard to microorganisms and their role in health and disease, because a number of lactic acid bacteria (LAB) in fermented food as well as yogurt starter cultures exerted antioxidant activity in vitro and in vivo (Kim et al., 2005, 2006; Li et al., 2012). In skim milk fermented with Lactobacillus casei, the 1,1-diphenyl-2-picrylhydrazyl (DPPH) radical-scavenging activity was increased, suggesting that casein-derived peptides are one of the factors enhancing radical-scavenging activity. Nishino et al. (2000) noted that a $\kappa$ -casein-derived peptide with DPPH radical scavenging activity was found in milk fermented with $L$. delbrueckii spp. bulgaricus.

Fermented milk has been reported to have increased scavenging activity, which was suggested to be related to milk proteins are soybean protein-derived peptides (Sirirat and Jelena, 2010). It has been previously reported that peptides released as a result of protein hydrolysis of substrates, extracellular metabolites, and/or product of cell lysis derived from dairy products showed some antioxidant potential (Yang et al., 2000). In addition, polyphenols found in soybeans demonstrated the potential ability to scavenge free oxygen-derived radicals. Virtanen et al. (2007) reported that the DPPH values of a milk protein hydrolysate from LAB-fermented skim milk increased with increasing fermentation time. Therefore, the consumption of foods fermented with LAB that show antioxidant activity may be beneficial for human health by improving the total antioxidant status and decreasing oxidative stress (Songisepp et al., 2005). For most customers, yogurt has long been recognized as a food product with many desirable effects and nutritional value. The available conventional bacteria used as yogurt starter cultures for dairy products are L. acidophilus, L. bulgaricus, $L$. casei, $S$. thermophilus, Bifidobacterium longum, and B. bifidum (Lourens-Hattingh and Viljoen, 2001). Fermented vegetables contain many LAB. Thus, in this study, we evaluated the antioxidant properties of plain yogurt and soy yogurt fermented with desirable yogurt starter cultures, i.e., LAB with antioxidant activity isolated from pickled cabbage. In particular, the purpose of this study was to evaluate the physicochemical and microbiological characteristics and antioxidant properties, including the in vitro ability to scavenge DPPH and superoxide anion radicals, ferrous ion-chelating capability, reducing power, superoxide dismutase (SOD) activity, and lipid peroxidation of the plain yogurt and soy yogurt during storage at $4^{\circ} \mathrm{C}$.

\section{Materials and Methods}

\section{Isolation and identification of LAB}

Seven samples of pickled cabbage were prepared after fermentation for 7 days at $4{ }^{\circ} \mathrm{C}$ with salt, sugar, vinegar, and whole pepper. Samples were collected aseptically and homogenized in sterile phosphate buffer solution (PBS; $0.85 \%$ $\mathrm{NaCl}, 2.68 \mathrm{mM} \mathrm{KCl}, 10 \mathrm{mM} \mathrm{Na}_{2} \mathrm{HPO}_{4}$, and $1.76 \mathrm{mM} \mathrm{KH}_{2} \mathrm{PO}_{4}$, $\mathrm{pH}$ 7.0) for 2 min with a Waring blender (Waring Products Division, USA). Then, LAB present in the samples were isolated using de Man, Rogosa and Sharpe (MRS) agar (BD Difco Co., USA) plates after culturing under aerobic conditions for $48 \mathrm{~h}$ at $37^{\circ} \mathrm{C}$. After purification, stock cultures of the isolated strains were stored at $-20^{\circ} \mathrm{C}$ in MRS broth containing sterile glycerol $(20 \%, \mathrm{v} / \mathrm{v})$. The resistance of the isolated strains to hydrogen peroxide $(0.5 \mathrm{mM})$ was estimated according to the method of Buchmeier et al. (1997). Strains that showed high resistance to hydrogen peroxide were tentatively identified by their sugar fermentation patterns using the API 50 CHL kit (bioMérieux Co., France), and the results were confirmed by $16 \mathrm{~S}$ rRNA gene sequence analysis. The universal primers, $27 \mathrm{~F}$ (5'-AGAGTTTGAT CCTGGCTCAG-3') and 1492R (5'-GGTT ACCTTGTTA CGACTT-3') were used for amplifying the $16 \mathrm{~S}$ rRNA sequence. Temperature cycling conditions for polymerase chain reactions (PCR, Bio-Rad Laboratories Ltd, Canada) were as follows: denaturation at $94^{\circ} \mathrm{C}$ for $1 \mathrm{~min}$, annealing at $55^{\circ} \mathrm{C}$ for $1 \mathrm{~min}$, and extension at $72^{\circ} \mathrm{C}$ for $2 \mathrm{~min}$, for a total of 30 cycles. PCR products were analyzed on $1 \%(\mathrm{w} / \mathrm{v})$ agarose gels and purified with the QIA-quick PCR purification system (Qiagen, USA). Then, partial 16S gene sequences were compared with sequences in the GenBank nucleotide database from the National Center for Biotechnology Information.

\section{Preparation of yogurt samples}

Among the isolated LAB with high resistance to hydrogen peroxide, the strains that are used as conventional yogurt starter cultures were cultivated in MRS broth at $37^{\circ} \mathrm{C}$ until the late exponential phase and then centrifuged $\left(7,000 \times \mathrm{g}, 10 \mathrm{~min}, 4^{\circ} \mathrm{C}\right)$. The cell pellet was washed twice with PBS ( $\mathrm{pH}$ 7.0), resuspended in the same buffer, and used for yogurt production. Fresh milk purchased at a local market was preheated to $63^{\circ} \mathrm{C}$ for $30 \mathrm{~min}$, at which stage skim milk powder $(5 \%$, w/v) was added, followed by cooling to $40^{\circ} \mathrm{C}$ before inoculation. Meanwhile, soymilk was prepared according to the procedure described by Wang et al. (2002). First, whole soybeans were washed and soaked overnight in distilled water at room temperature. Then, the hydrated beans were ground for $5 \mathrm{~min}$ with water at a ratio of 1:3 (w/v) using a Waring blender. After the slurry was filtered through a nylon 100-mesh filter sack, a 
milky-looking liquid, known as soybean milk, was obtained. The suspension was pasteurized at $90^{\circ} \mathrm{C}$ for $15 \mathrm{~min}$ and the soymilk was then allowed to cool to $40^{\circ} \mathrm{C}$ before inoculation with the starter culture. Pasteurized skim milk and soymilk were aseptically inoculated with $5 \%(\mathrm{v} / \mathrm{v})$ of the starter strain adjusted to an initial population of $1.0 \times 10^{3} \mathrm{CFU} / \mathrm{ml}$. The inoculated milk samples were mixed thoroughly and incubated for $30 \mathrm{~h}$ at $37^{\circ} \mathrm{C}$. After fermentation, yogurt samples were drawn at 2-day intervals to examine the physicochemical and microbiological characteristics and antioxidant activities of plain yogurt and soy yogurt during storage at $4^{\circ} \mathrm{C}$.

\section{Enumeration of LAB}

Bacterial enumeration was performed once in 2 days during 8 days of storage at $4{ }^{\circ} \mathrm{C}$. Yogurt samples $(5 \mathrm{~g})$ were homogenized with $45 \mathrm{ml}$ of sterilized PBS ( $\mathrm{pH} 7.0$ ) for $1 \mathrm{~min}$ and diluted 10-fold with saline. Viable cell counts of LAB were determined by dilution plating on MRS agar plates. After incubation at $37^{\circ} \mathrm{C}$ for $48 \mathrm{~h}$, visible colonies of each strain were then counted and expressed as colony-forming units (CFU) per gram.

\section{Measurement of $\mathrm{pH}$, titratable acidity, and viscosity}

The $\mathrm{pH}$ of the yogurt samples was monitored directly using a digital $\mathrm{pH}$ meter (Fisher Scientific, USA) calibrated with standard buffer solutions. Titratable acidity was determined by titration with $0.1-\mathrm{N} \mathrm{NaOH}$ to the end point, $\mathrm{pH} 7.0$ at $25^{\circ} \mathrm{C}$. Viscosity was determined using a Brookfield viscometer (Brookfiled Engineering Laboratories, Inc., USA) equipped with a spindle (No. 3) rotating at $50 \mathrm{rpm}$ at 1 -min intervals.

\section{DPPH radical scavenging activity}

The scavenging effect of plain yogurt and soy yogurt on DPPH radicals was evaluated using the method of Shimada et al. (1992), with some modifications. In brief, the DPPH radical (Sigma-Aldrich, USA) solution $\left(4.0 \times 10^{-4} \mathrm{M}\right)$ was prepared in $95 \%$ ethanol. Yogurt samples $(1 \mathrm{ml}, 2 \mathrm{mg} / \mathrm{ml})$ were added to equal volume of the ethanolic DPPH radicals solution. The reaction mixtures were shaken vigorously and left to stand for $30 \mathrm{~min}$ at room temperature in the dark. After centrifugation at $8,000 \times g$ for $10 \mathrm{~min}$, the reduction of DPPH free radicals was measured by reading the absorbance at $517 \mathrm{~nm}$. Scavenging effect of DPPH radicals was calculated by using the following equation: DPPH radical-scavenging activity $(\%)=[($ absorbance of blank-absorbance of sample)]/(absorbance of blank) $\times 100$. Ascorbic acid and butylated hydroxylanisol (BHA) at a concentration of $0.1 \mathrm{mg} / \mathrm{ml}$ were used as positive controls.

\section{Superoxide anion radical scavenging activity}

The effect of plain yogurt and soy yogurt on the generation of superoxide was measured as the reduction of nitroblue tetrazolium (NBT) using a spectrophotometer according to the method described by Nishikimi et al. (1972). Superoxide anion radicals were generated in a non-enzymatic phenazine methodsulfate-nicotinamide adenine dinuleotide (PMS-NAD) system. Yogurt samples $(0.5 \mathrm{ml}, 2 \mathrm{mg} / \mathrm{ml})$ were mixed with the reaction solution containing $0.5 \mathrm{ml}$ of PMS $(120 \mu \mathrm{M}), 0.5 \mathrm{ml}$ of NAD $(936 \mu \mathrm{M})$, and $0.5 \mathrm{ml}$ of NBT $(300 \mu \mathrm{M})$ dissolved in PBS $(\mathrm{pH} 7.4)$ and reacted for $5 \mathrm{~min}$ at room temperature. The absorbance of the solution was measured at $560 \mathrm{~nm}$. Superoxide anion radical scavenging activity of the sample was then calculated according to the following equation: Scavenging effect $(\%)=(1$-absorbance of sample/absorbance of control $) \times$ 100. Ascorbic acid and BHA at a concentration of $0.1 \mathrm{mg} / \mathrm{ml}$ were used as positive controls.

\section{Chelating activity on ferrous ions}

The chelating effect of the yogurt samples was determined according to the method of Decker and Welch (1990), with some modifications. The reaction mixture consisted of the yogurt sample $(1 \mathrm{ml}, 2 \mathrm{mg} / \mathrm{ml})$ dissolved in deionized water $(3.7 \mathrm{ml})$ and $2 \mathrm{mM}$ ferrous chloride $(0.1 \mathrm{ml})$. After $3 \mathrm{~min}$, the reaction was inhibited by the addition of $5 \mathrm{mM}$ ferrozine $(0.2$ $\mathrm{ml})$. The mixture was shaken vigorously and left to stand for 10 min at room temperature. The absorbance of the resulting solution was measured at $562 \mathrm{~nm}$. The chelating effect (\%) of yogurt samples was calculated from equation as follows. $\mathrm{Fe}^{2+}$ chelating activity $(\%)=(1$-absorbance of sample/absorbance of control) $\times 100$. Ethylenediaminetetracetic acid (EDTA) at a concentration of $0.1 \mathrm{mg} / \mathrm{ml}$ was used as positive controls.

\section{Reducing power determination}

The reducing power of the yogurt samples was determined according to the method of Oyaizu (1986), with some modifications. Briefly, $2.5 \mathrm{ml}$ of yogurt sample $(2 \mathrm{mg} / \mathrm{ml})$ was mixed with an equal volume of $1 \%$ potassium ferricyanide and $0.2 \mathrm{M}$ PBS ( $\mathrm{pH}$ 6.5). The mixture was heated for $20 \mathrm{~min}$ at 5 $0{ }^{\circ} \mathrm{C}$ and an equal volume of $10 \%$ trichloroacetic acid was then added to the mixture. After centrifugation at $2,000 \times g$ for 10 min, the upper layer $(5 \mathrm{ml})$ was mixed with $5 \mathrm{ml}$ of distilled water and $1 \mathrm{ml}$ of a $0.1 \%$ ferric chloride solution and the reaction was continued for $10 \mathrm{~min}$. The absorbance of the solution was measured at $700 \mathrm{~nm}$. Ascorbic acid and BHA at a concentration of $0.1 \mathrm{mg} / \mathrm{ml}$ were used as positive controls.

\section{Assay for SOD}

The SOD activity of the yogurt samples was determined according to the method of Granelli et al. (1995). Yogurt sample $(0.1 \mathrm{ml}, 2 \mathrm{mg} / \mathrm{ml})$ were mixed with $3 \mathrm{ml}$ of a reaction solution 
containing cytochrome c $(24 \mu \mathrm{M})$, xanthine $(100 \mu \mathrm{M})$, diethylentriaminpentaacetic acid $(100 \mu \mathrm{M})$, and xanthine oxidase $(33 \mu \mathrm{U})$ in Tris- $\mathrm{HCl}(50 \mathrm{mM}$; $\mathrm{pH} 8.5)$. The mixture was kept for $20 \mathrm{~min}$ at room temperature and the absorbance of the test solution was measured at $340 \mathrm{~nm}$. One unit of SOD activity was defined as the amount of enzyme required to cause a $20 \%$ inhibition of the cytochrome $\mathrm{c}$ reduction activity of the tested sample.

\section{Inhibition of linoleic acid peroxidation}

The inhibitory effect of the yogurt samples manufactured with the tested strains on lipid peroxidation was evaluated by the thiocyanate method (Osawa and Namiki, 1981), with some modifications. Yogurt samples $(2 \mathrm{mg} / \mathrm{ml}, 0.5 \mathrm{ml})$ in deionized water were mixed with $2.5 \mathrm{ml}$ of a linoleic acid emulsion, which was prepared by mixing equal volumes of linoleic acid, Tween 20, and PBS (0.02 M; pH 7.0). This mixture was then incubated for $24 \mathrm{~h}$ at $37^{\circ} \mathrm{C}$ in the dark to accelerate oxidation. To measure the degree of lipid peroxidation, $75 \%$ ethanol $(4.7$ $\mathrm{ml}), 30 \%$ ammonium thiocyanate $(0.1 \mathrm{ml})$, and $20 \mathrm{mM}$ ferrous chloride $(0.1 \mathrm{ml})$ in $3.5 \% \mathrm{HCl}$ were added to the sample solution $(0.1 \mathrm{ml})$. After stirring for $3 \mathrm{~min}$, the peroxide value was determined by reading the absorbance at $500 \mathrm{~nm}$ using a spectrophotometer. The percentage of inhibition of linoleic acid peroxidation was defined as follows: $(\%)=(1$-absorbance of sample/absorbance of control) $\times 100$. Ascorbic acid and BHA at a concentration of $0.1 \mathrm{mg} / \mathrm{ml}$ were used as positive controls.

\section{Statistical analysis}

Results on physicochemical and microbiological properties and antioxidant activities of plain yogurt and soy yogurt were expressed as the mean \pm standard deviation (SD) of triplicate determinations. Data were analyzed by one-way analysis of variance (ANOVA) using the statistical software package SPSS 12.0 (Ver. 12.0, USA). Multiple comparisons for significant differences between treatment groups were undertaken by Duncan's multiple range tests at the significance level of $P<0.05$.

\section{Results and Discussion}

\section{Identification of $L A B$}

As summarized in Table 1, the LAB strains that were isolated from pickled cabbage and that showed high resistance to hydrogen peroxide were identified as $L$. casei PC05, $L$. acidophilus PC16, L. cellobiosus PC19, Leuconostoc mesenteroides PC28, L. brevis PC31, and L. plantarum PC33 with confidence intervals of $92.8 \%-99.8 \%$ according to the results of carbohydrate utilization tests using the API $50 \mathrm{CHL}$ system. Among the tested LAB, the strains PC05, PC31, and PC33 had a good identification level in the API $50 \mathrm{CHL}$ test. The identification results of the strains PC05, PC16, and PC31 obtained using the API system were consistent with those obtained using $16 \mathrm{~S}$ rRNA sequencing. However, according to their 16S rRNA sequences, the strains PC19, PC28, and PC33 were identified as $L$. fermentum, $L$. mesenteriodes subsp. mesenteroides, and $L$. plantarum subsp. plantarum, respectively; this result was different from the results of the API $50 \mathrm{CHL}$ test. The $16 \mathrm{~S}$ rRNA gene sequences of all tested strains showed more than 99\% similarity with the related strains in GenBank. Consequently, on the basis of the 16S rRNA gene sequences, the isolates were identified as $L$. casei PC05, L. acidophilus PC16, L. fermentum PC19, L. mesenteriodes subsp. mesenteroides PC28, L. brevis PC31, and L. plantarum subsp. plantarum PC33.

LAB improve the shelf-life of raw vegetables because they produce unique metabolic substances and antimicrobial agents and increase the nutritional value and organoleptic quality of food features, e.g., flavor, aroma, and texture, due to the conversion of sugars to organic acids and ethanol (Bourdichon et al., 2012). LAB strains such as Leuconostoc, Lactobacillus, and Pediococcus, responsible for the fermentation of vegetables, can rapidly grow in fermented plant-based materials because many vegetables contain nutrients (e.g. sugar, vitamin, and mineral) essential for microbial growth and survival (Peres et al., 2012). Although LAB are the principal microorganisms

Table 1. Identification of LAB isolated from pickled cabbage by API 50CHL and 16S rRNA sequencing

\begin{tabular}{|c|c|c|c|c|c|}
\hline \multirow[b]{2}{*}{ Strain } & \multicolumn{2}{|c|}{ API 50CHL } & \multicolumn{2}{|l|}{$16 \mathrm{~S}$ rRNA sequencing } & \multirow[b]{2}{*}{ Identification } \\
\hline & Species affiliation & $\begin{array}{l}\text { Confidence } \\
(\%)\end{array}$ & $\begin{array}{l}\text { Related strain in NCBI } \\
\text { (Accession No.) }\end{array}$ & $\begin{array}{l}\text { Similarity } \\
(\%)\end{array}$ & \\
\hline $\mathrm{PC} 16$ & L. acidophilus & 95.7 & L. acidophilus NCFM (CP000033) & 99.6 & L. acidophilus $\mathrm{PC} 16$ \\
\hline PC19 & L. cellobiosus & 92.8 & L. fermentum NBRC3956 (AP008937) & 99.8 & L. fermentum PC19 \\
\hline $\mathrm{PC} 31$ & L. brevis & 99.8 & L. brevis ATCC14687 (EF120367) & 99.9 & L. brevis $\mathrm{PC} 31$ \\
\hline PC33 & L. plantarum & 98.7 & $\begin{array}{l}\text { L. plantarum subsp. plantarum ATCC14917 } \\
\text { (ACG201000098) }\end{array}$ & 99.9 & $\begin{array}{l}\text { L. plantarum subsp. } \\
\text { plantarum } \mathrm{PC} 33\end{array}$ \\
\hline
\end{tabular}


responsible for the natural fermentation of vegetables, the species isolated from fermented vegetables are highly dependent in the inherent microbes present in the raw materials, the characteristics of major substrates, oxygen content, and the final acidity of the products (Irkin and Songun, 2012). In particular, several kinds of LAB, including Pediococcus pentosaceus, $L$. fermentum, L. curvatus, L. plantarum, L. paracasei, L. case $i, L$. delbrueckii, L. brevis, L. mesenteroides, and Enterococcus faecalis have been found to be the dominant species in lactic acid fermentation of different vegetables, including pickled cabbage (Rivera-Espinoza and Gallardo-Navarro, 2010).

\section{Physiochemical and microbiological properties of plain yogurt and soy yogurt}

After fermentation of plain yogurt and soy yogurt using $L$. casei PC05 and L. acidophilus PC16, which are suitable for yogurt production, the physiochemical and microbiological properties of the yogurt samples were determined during cold storage, as shown in Table 2. The starter cultures inoculated with the tested strains grew well in plain yogurt and soy yogurt, and the number of viable cells after $30 \mathrm{~h}$ of fermentation ranged from $1.8 \pm 1.2 \times 10^{7}$ to $7.4 \pm 1.6 \times 10^{8} \mathrm{CFU} / \mathrm{g}$. The cell counts in plain yogurt fermented with the strains $L$. casei PC05 and $L$. acidophilus PC16 were significantly lower than those in soy yogurt $(P<0.05)$. Apparently, compared to skim milk, soymilk had a significant $(P<0.05)$ effect on the yogurt culture with regard to increasing the concentration of the tested strains during fermentation. At the end of storage $\left(8\right.$ days at $\left.4^{\circ} \mathrm{C}\right)$, the number of LAB cells in the yogurt samples reached values ranging from $2.9 \pm 1.5 \times 10^{7}$ to $7.5 \pm 1.9 \times 10^{8} \mathrm{CFU} / \mathrm{g}$, indicating that there was no significant difference $(P>0.05)$ compared with the initial cell counts in the samples before storage.

After fermentation, the $\mathrm{pH}$ of plain yogurt fermented with $L$. casei PC05 and L. acidophilus PC16 decreased to $4.02 \pm 0.12$ and $4.26 \pm 0.16$, respectively, whereas the $\mathrm{pH}$ of soy yogurts decreased to $3.90 \pm 0.16$ and $3.61 \pm 0.13$, respectively. Statistical analysis showed that the $\mathrm{pH}$ of soy yogurt fermented with $L$. acidophilus PC16 was significantly lower than that of plain yogurt $(P<0.05)$. Throughout cold storage, the $\mathrm{pH}$ values of both plain yogurt and soy yogurt were similar to the initial $\mathrm{pH}$.

The titratable acidity of plain yogurt fermented with the tested strains was $0.84 \pm 0.06$ and $0.94 \pm 0.09$, whereas that of soy yogurt was $0.94 \pm 0.08$ and $1.16 \pm 0.14$. The titratable acidity of soy yogurt was relatively higher than that of plain yogurt. The titratable acidity of the yogurt samples during cold storage did not change significantly $(P>0.05)$. These results demonstrate that the titratable acidity was affected by the change in the $\mathrm{pH}$ of the yogurt samples during fermentation.

The viscosity of the yogurt samples prepared with skim milk and soymilk varied as different starter cultures were used. Immediately after the fermentation, the initial viscosity of plain yogurt fermented with the strains PC05 and PC16 was 1119.7 \pm 3.5 and $1269.7 \pm 1.7 \mathrm{cps}$, respectively. In soy yogurt fermented with the strains $L$. casei PC05 and L. acidophilus

Table 2. Changes of viable cell counts, viscosity, $\mathrm{pH}$, and titratable acidity of plain yogurt and soy yogurt fermented with $L$. casei PC05 and $L$. acidophilus PC16 during cold storage

\begin{tabular}{|c|c|c|c|c|c|c|c|}
\hline \multirow{2}{*}{$\begin{array}{l}\text { Physicochemical } \\
\text { property }\end{array}$} & \multirow{2}{*}{ Strain } & \multirow{2}{*}{ Sample } & \multicolumn{5}{|c|}{ Storage time (days) } \\
\hline & & & 0 & 2 & 4 & 6 & 8 \\
\hline \multirow{4}{*}{$\begin{array}{l}\text { Viable cell counts } \\
\quad(\mathrm{CFU} / \mathrm{ml})\end{array}$} & \multirow{2}{*}{$\mathrm{PC} 05$} & Plain yogurt & $1.8 \pm 1.2 \times 10^{7 \mathrm{~d}}$ & $3.0 \pm 0.8 \times 10^{7 \mathrm{~d}}$ & $2.5 \pm 1.0 \times 10^{7 \mathrm{~d}}$ & $1.6 \pm 1.1 \times 10^{7 \mathrm{~d}}$ & $2.9 \pm 1.5 \times 10^{7 d}$ \\
\hline & & Soy yogurt & $6.6 \pm 2.3 \times 10^{7 \mathrm{c}}$ & $6.8 \pm 1.9 \times 10^{7 \mathrm{c}}$ & $5.8 \pm 2.7 \times 10^{7 \mathrm{c}}$ & $7.0 \pm 2.5 \times 10^{7 \mathrm{c}}$ & $6.3 \pm 1.8 \times 10^{7 \mathrm{c}}$ \\
\hline & \multirow{2}{*}{$\mathrm{PC} 16$} & Plain yogurt & $1.1 \pm 2.6 \times 10^{8 \mathrm{~b}}$ & $2.5 \pm 1.8 \times 10^{8 \mathrm{~b}}$ & $1.5 \pm 0.9 \times 10^{8 \mathrm{~b}}$ & $2.6 \pm 1.2 \times 10^{8 \mathrm{~b}}$ & $1.0 \pm 0.9 \times 10^{8 b}$ \\
\hline & & Soy yogurt & $7.4 \pm 1.6 \times 10^{8 \mathrm{a}}$ & $8.0 \pm 2.2 \times 10^{8 \mathrm{a}}$ & $7.6 \pm 2.0 \times 10^{8 \mathrm{a}}$ & $7.7 \pm 1.5 \times 10^{8 \mathrm{a}}$ & $7.5 \pm 1.9 \times 10^{8 \mathrm{a}}$ \\
\hline \multirow[t]{4}{*}{$\mathrm{pH}$} & \multirow{2}{*}{ PC05 } & Plain yogurt & $4.02 \pm 0.12^{\mathrm{a}}$ & $4.15 \pm 0.11^{\mathrm{a}}$ & $4.01 \pm 0.17^{\mathrm{a}}$ & $4.21 \pm 0.22^{\mathrm{a}}$ & $4.23 \pm 0.15^{\mathrm{a}}$ \\
\hline & & Soy yogurt & $3.90 \pm 0.16^{\mathrm{a}}$ & $4.02 \pm 0.28^{\mathrm{a}}$ & $3.99 \pm 0.27^{\mathrm{a}}$ & $4.02 \pm 0.13^{\mathrm{a}}$ & $4.10 \pm 0.14^{\mathrm{a}}$ \\
\hline & \multirow[b]{2}{*}{$\mathrm{PC} 16$} & Plain yogurt & $4.26 \pm 0.16^{\mathrm{a}}$ & $4.22 \pm 0.18^{\mathrm{a}}$ & $4.35 \pm 0.18^{\mathrm{a}}$ & $4.26 \pm 0.23^{\mathrm{a}}$ & $4.29 \pm 0.15^{\mathrm{a}}$ \\
\hline & & Soy yogurt & $3.61 \pm 0.13^{\mathrm{b}}$ & $3.73 \pm 0.18^{b}$ & $3.77 \pm 0.16^{\mathrm{b}}$ & $3.59 \pm 0.13^{\mathrm{b}}$ & $3.67 \pm 0.12^{\mathrm{b}}$ \\
\hline \multirow{4}{*}{$\begin{array}{c}\text { Titratable acidity } \\
(\%)\end{array}$} & \multirow{2}{*}{$\mathrm{PC} 05$} & Plain yogurt & $0.84 \pm 0.06^{\mathrm{bB}}$ & $0.90 \pm 0.09^{\mathrm{abAB}}$ & $0.83 \pm 0.08^{\mathrm{bB}}$ & $0.91 \pm 0.02^{\mathrm{bAB}}$ & $0.84 \pm 0.05^{\mathrm{cB}}$ \\
\hline & & Soy yogurt & $0.94 \pm 0.08^{\mathrm{abAB}}$ & $0.88 \pm 0.07^{\mathrm{bB}}$ & $0.93 \pm 0.09^{\mathrm{abAB}}$ & $0.96 \pm 0.06^{\mathrm{abAB}}$ & $0.97 \pm 0.11^{\mathrm{bcAB}}$ \\
\hline & \multirow{2}{*}{ PC16 } & Plain yogurt & $0.94 \pm 0.09^{\mathrm{abB}}$ & $0.85 \pm 0.16^{\mathrm{bC}}$ & $0.89 \pm 0.07^{\mathrm{abC}}$ & $0.98 \pm 0.11^{\mathrm{abAB}}$ & $0.99 \pm 0.06^{\mathrm{bAB}}$ \\
\hline & & Soy yogurt & $1.16 \pm 0.14^{\mathrm{aAB}}$ & $1.15 \pm 0.06^{\mathrm{aAB}}$ & $1.27 \pm 0.11^{\mathrm{aA}}$ & $1.08 \pm 0.07^{\mathrm{aB}}$ & $1.25 \pm 0.08^{\mathrm{aA}}$ \\
\hline \multirow[t]{4}{*}{ Viscosity (cps) } & \multirow{2}{*}{$\mathrm{PC} 05$} & Plain yogurt & $1119.7 \pm 3.5^{\mathrm{dBC}}$ & $1109.7 \pm 1.6^{\mathrm{dBC}}$ & $1124.7 \pm 1.9^{\mathrm{dB}}$ & $1101.7 \pm 2.7^{\mathrm{dC}}$ & $1135.7 \pm 1.7^{\mathrm{dAB}}$ \\
\hline & & Soy yogurt & $1353.7 \pm 3.6^{\mathrm{b}}$ & $1364.7 \pm 2.3^{\mathrm{b}}$ & $1360.0 \pm 2.0^{\mathrm{b}}$ & $1354.0 \pm 1.6^{\mathrm{b}}$ & $1351.0 \pm 2.4^{\mathrm{b}}$ \\
\hline & \multirow{2}{*}{ PC16 } & Plain yogurt & $1269.7 \pm 1.7^{\mathrm{cB}}$ & $1250.3 \pm 1.2^{\mathrm{cA}}$ & $1268.7 \pm 2.5^{\mathrm{cB}}$ & $1239.3 \pm 2.5^{\mathrm{cA}}$ & $1259.0 \pm 1.8^{\mathrm{cB}}$ \\
\hline & & Soy yogurt & $1419.0 \pm 1.9^{\mathrm{a}}$ & $1428.7 \pm 1.6^{\mathrm{a}}$ & $1420.1 \pm 3.9^{\mathrm{a}}$ & $1415.2 \pm 1.3^{\mathrm{a}}$ & $1432.7 \pm 3.2^{\mathrm{a}}$ \\
\hline
\end{tabular}

Data are means \pm SD from triplicate determinations.

${ }^{\mathrm{a}-\mathrm{d}}$ Values within a column with different superscripts are significantly each groups at $p<0.05$ by Duncan's multiple range test.

${ }^{\mathrm{A}-\mathrm{C}}$ Values within a row with different superscripts are significantly each groups at $p<0.05$ by Duncan's multiple range test. 
PC16, the viscosity was increased by about $5-15 \%$ compared to that of plain yogurt. During storage for 8 days at $4{ }^{\circ} \mathrm{C}$, no significant changes in the viscosity of the yogurt samples were observed. However, the differences in viscosity are probably related to the final number of starter bacteria in the yogurt.

Our results are in agreement with those of Noni et al. (2004), who reported that L. bulgaricus and Streptococcus thermophilus counts in yogurt samples ranged between $10^{7}$ and $10^{8} \mathrm{CFU} / \mathrm{g}$ for 10 days. Mital and Steinkraus (1974) reported a cell count of $6.8 \times 10^{7} \mathrm{CFU} / \mathrm{ml}$ for soymilk after fermentation for $16-18$ h. Ouwehand and Salminen (1998) reported that yogurt prepared with bovine and soymilk had a cell count of around $2.4 \times 10^{8} \mathrm{CFU} / \mathrm{ml}$. The results obtained in this study are also in accordance with the finding of Hamann and Marth (1984), who demonstrated that yogurt bacteria such as S. thermophilus and L. delbrueckii ssp. bulgaricus survive well in yogurt throughout the shelf-life. It has been suggested that the amount of LAB contained in fermented dairy products should be more than $10^{7}$ $\mathrm{CFU} / \mathrm{ml}$ in order to exert beneficial health effects in the gastrointestinal tract (Mital and Steinkraus, 1974).

The roles of starter cultures such as streptococci and lactobacilli, which are used in yogurt production, are milk acidification by producing lactic acid from lactose, formation of major aromatic compounds (acetaldehyde), and development of viscosity resulting in unique textures (Zourari et al., 1992). Lactic acid produced by LAB may cause the demineralization of casein micelles during yogurt storage and lead to excessive acidification, which affects the organoleptic properties of fermented products (Zourari et al., 1992). Lactic acid fermentation resulted in a decrease in the $\mathrm{pH}$, whereas the titratable acidity increased. Acid production in yogurt depends on the growth of microorganisms and their ability to utilize carbohydrates in milk (Ghorbani et al., 2012). As a result, the metabolic by-products, i.e., several organic acids that induce the increase in titratable acidity and the decrease in the $\mathrm{pH}$, cause coagulation of the fermented milk and, hence, resulting in yogurt with high viscosity. The amount of lactic acid depends on the strains used. Although the ideal $\mathrm{pH}$ of yogurt may range from 4.0 to 4.1 , the $\mathrm{pH}$ of commercial yogurt is usually in the range of 3.7-4.3 (Hamann and Marth, 1984). Sokolinska et al. (2004) indicated that after inoculation with the bacterial cultures, the $\mathrm{pH}$ of milk decreased from 6.7 to 4.55 during the manufacturing process of yogurt. Chougrani $e t$ al. (2008) indicated that there is a proportional relationship between the amount of starter culture used for inoculation and the degree of acidity, because the latter increases depending on the inoculation dose. S. thermophilus produces texturizing agents (exopolysaccharides) that might interact with proteins contained in milk and increase the viscosity and rheological quality of yogurt (Rawson and Marshall, 1997). Therefore, the viscosity of yogurt is influenced by various factors such as material compositions, type of starter cultures, heating conditions, and stabilizers (Trachoo, 2002).

\section{Scavenging effect of plain yogurt and soy yogurt upon DPPH free radicals}

The DPPH free radical scavenging activities of the yogurt samples obtained after fermentation of skim milk and soymilk are given in Table 3. Plain yogurt and soy yogurt fermented with $L$. casei PC05 displayed a DPPH radical scavenging activity of $37.3 \pm 2.2 \%$ and $61.2 \pm 0.8 \%$, respectively. Yogurt samples fermented with $L$. acidophilus PC16 exhibited

Table 3. Changes of DPPH and superoxide anion radical scavenging of plain yogurt and soy yogurt fermented with $L$. casei PC05 and $L$. acidophilus PC16 during cold storage

\begin{tabular}{|c|c|c|c|c|c|c|c|}
\hline \multirow{2}{*}{$\begin{array}{c}\text { Radical scavenging } \\
\text { activity (\%) }\end{array}$} & \multirow{2}{*}{ Strain } & \multirow{2}{*}{ Sample } & \multicolumn{5}{|c|}{ Storage time (days) } \\
\hline & & & 0 & 2 & 4 & 6 & 8 \\
\hline \multirow{6}{*}{ DPPH } & \multirow{2}{*}{$\mathrm{PC} 05$} & Plain yogurt & $37.3 \pm 2.2^{\mathrm{d}}$ & $35.4 \pm 1.6^{\mathrm{d}}$ & $36.6 \pm 2.4^{\mathrm{d}}$ & $36.8 \pm 1.5^{\mathrm{d}}$ & $37.4 \pm 2.1^{\mathrm{d}}$ \\
\hline & & Soy yogurt & $61.2 \pm 0.8^{\mathrm{b}}$ & $62.3 \pm 1.1^{\mathrm{b}}$ & $61.1 \pm 1.7^{\mathrm{b}}$ & $61.9 \pm 2.5^{\mathrm{b}}$ & $62.2 \pm 4.0^{\mathrm{b}}$ \\
\hline & \multirow{2}{*}{ PC16 } & Plain yogurt & $51.3 \pm 2.0^{\mathrm{cB}}$ & $53.4 \pm 1.5^{\mathrm{cAB}}$ & $54.1 \pm 1.4^{\mathrm{cAB}}$ & $54.2 \pm 2.5^{\mathrm{cAB}}$ & $55.0 \pm 3.6^{\mathrm{cAB}}$ \\
\hline & & Soy yogurt & $76.9 \pm 2.0^{\mathrm{a}}$ & $75.3 \pm 2.2^{\mathrm{a}}$ & $76.7 \pm 1.2^{\mathrm{a}}$ & $76.9 \pm 0.9^{\mathrm{a}}$ & $77.7 \pm 0.9^{\mathrm{a}}$ \\
\hline & \multirow{2}{*}{\multicolumn{2}{|c|}{$\begin{array}{l}\text { Ascorbic acid } \\
\text { BHA }\end{array}$}} & \multicolumn{5}{|c|}{$68.1 \pm 4.3$} \\
\hline & & & & & $89.7 \pm 1.7$ & & \\
\hline \multirow{6}{*}{ Superoxide anion } & \multirow{2}{*}{$\mathrm{PC} 05$} & Plain yogurt & $59.3 \pm 1.0^{\mathrm{b}}$ & $59.6 \pm 2.5^{b}$ & $58.9 \pm 1.2^{\mathrm{b}}$ & $58.3 \pm 1.0^{\mathrm{b}}$ & $59.6 \pm 1.5^{\mathrm{b}}$ \\
\hline & & Soy yogurt & $64.4 \pm 1.0^{\mathrm{a}}$ & $65.4 \pm 1.0^{\mathrm{a}}$ & $64.4 \pm 2.6^{\mathrm{a}}$ & $64.7 \pm 2.1^{\mathrm{a}}$ & $64.3 \pm 1.0^{\mathrm{a}}$ \\
\hline & \multirow{2}{*}{$\mathrm{PC} 16$} & Plain yogurt & $38.1 \pm 0.6^{\mathrm{cA}}$ & $39.8 \pm 2.0^{\mathrm{cA}}$ & $38.8 \pm 2.0^{\mathrm{cA}}$ & $37.1 \pm 4.2^{\mathrm{dAB}}$ & $35.4 \pm 2.1^{\mathrm{dB}}$ \\
\hline & & Soy yogurt & $41.8 \pm 2.0^{\mathrm{c}}$ & $42.5 \pm 2.6^{\mathrm{c}}$ & $42.1 \pm 1.6^{\mathrm{c}}$ & $42.5 \pm 2.5^{\mathrm{c}}$ & $40.6 \pm 2.9^{\mathrm{c}}$ \\
\hline & \multicolumn{2}{|c|}{ Ascorbic acid } & \multicolumn{5}{|c|}{$92.4 \pm 2.5$} \\
\hline & \multicolumn{2}{|c|}{ BHA } & \multicolumn{5}{|c|}{$89.9 \pm 1.9$} \\
\hline
\end{tabular}

Data are means \pm SD from triplicate determinations.

${ }^{\mathrm{a}-\mathrm{d}}$ Values within a column with different superscripts are significantly each groups at $p<0.05$ by Duncan's multiple range test.

${ }^{\mathrm{AB}}$ Values within a row with different superscripts are significantly each groups at $p<0.05$ by Duncan's multiple range test. 
remarkably higher antioxidant activity in scavenging DPPH radicals than those fermented with $L$. case $i$ PC05. Furthermore, the DPPH scavenging activity of soy yogurt fermented with $L$. casei PC05 and L. acidophilus PC16 was significantly $(P<0.05)$ higher than that of plain yogurt. After storage for 8 days, the DPPH free radical scavenging activity of soy yogurt was significantly $(P<0.05)$ greater than that of plain yogurt. At 0.1 $\mathrm{mg} / \mathrm{ml}$, the scavenging activity of ascorbic acid and BHA was $68.1 \pm 4.3 \%$ and $89.7 \pm 1.7 \%$, respectively. The DPPH free radical scavenging activity of plain yogurt was significantly lower than that of the positive controls $(P<0.05)$. However, the scavenging activity of soy yogurt fermented with $L$. acidophilus PC16 was higher than the antioxidant activity of ascorbic acid (approximately 8\%). These results indicated that the development of radical scavenging activity correlated with the bacterial growth of L. acidophilus PC16, which grew faster and exhibited higher cell counts than $L$. casei PC05 during fermentation.

DPPH is a free radical compound that is widely used to determine the free radical scavenging activity of a potential antioxidant. The mechanism by which antioxidants exert DPPH radical scavenging activity is based on their hydrogen or electron donating ability, and this radical scavenging activity is visually noticeable as a change in the color of DPPH, i.e., from purple to yellow, in the presence of an antioxidant (Liu et al., 2005a; Zhang et al., 2011). Li et al. (2012) demonstrated that L. plantarum C88 isolated from traditional Chinese fermented foods had the highest radical scavenging activity (53.05\%), followed by $L$. plantarum C10, S3-8, S5-6, and K25, at a dose of $10^{10} \mathrm{CFU} / \mathrm{ml}$. Abubakr et al. (2012) noted that milk fermented with $L$. plantarum ATCC 8014 showed DPPH values of $>50 \%$. DPPH activity was significantly affected by the LAB species and fermentation time.

During the fermentation of soymilk, the major constituents including soy proteins, oligosaccharides such as raffinose and stachyose, and other soy carbohydrates are utilized bacterial growth (Liu et al., 2005a). In addition, soy protein and phytochemicals (isoflavones), which are enriched in soybean, showed greater antioxidant ability than casein in milk (Vij et al., 2011). Our results may suggest that the radical scavenging activity was derived, at least in part, from proteins and peptides in milk and soybean released by the strains that were isolated from pickled cabbage. In addition, this activity may be dependent on specific proteolytic enzymes obtained from the bacterial strains.

\section{Scavenging effect of plain yogurt and soy yogurt upon superoxide anion radicals}

As shown in Table 3, plain yogurt and soy yogurt fermented with the tested strains possess superoxide anion radical scavenging activity. In fermented plain yogurt and soy yogurt, the superoxide anion radical scavenging activity was determined to be in the range of $38.1 \pm 0.6 \%$ to $64.4 \pm 1.0 \%$; it varied with the starter organism used. The scavenging activity of fermented soy yogurt was higher than that of plain yogurt. Yogurt samples fermented with $L$. casei PC05 exhibited noticeably higher superoxide anion radical scavenging activity than those fermented with $L$. acidophilus PC16 $(P<0.05)$. Ascorbic acid and BHA, which have very high superoxide anion radical scavenging activity, showed $92.4 \%$ and $89.9 \%$ inhibition at a concentration of $0.1 \mathrm{mg} / \mathrm{ml}$, respectively. It was noted that regardless of the starter culture used, the superoxide anion radical scavenging activity of plain yogurt and soy yogurt did not change during storage. According to the results obtained, the development of superoxide anion radicals scavenging activity was dependent on the strain used and storage did not significantly affect the scavenging activity of the yogurt samples.

Wang et al. (2006) reported that the superoxide anion radical scavenging activity of soymilk prepared without fermentation was $32.44 \%$, whereas that of fermented soymilk was in the range of $43.08-65.04 \%$, depending on the starter organisms used. In addition, it is interesting to note that after the initial period $(8 \mathrm{~h})$ of fermentation, the scavenging activity of fermented soymilk containing $S$. thermophilus was significantly higher $(P<0.05)$ than that of soymilk containing L. acidophilus; this difference increased during the fermentation process. Compared to other free radicals, superoxide radicals are rather unreactive. However, superoxide radicals indirectly initiate lipid oxidation as a result of superoxides and hydrogen peroxide that serve as precursors of singlet oxygen and hydroxyl radicals. Highly reactive superoxide anion radicals are capable of oxidizing cellular components and biological macromolecules, resulting in cell death and tissue damage (Zhang et al., 2011).

Yang et al. (2000) demonstrated that soybean and soymilk contain isoflavones such as daidzein and genistein, which are antioxidants that might also possess superoxide anion-scavenging activity, similar to flavonoids. The increase in the isoflavone content during fermentation leads to the increased superoxide anion-scavenging activity observed in fermented soymilk, which might result in the production of SOD by LAB (Wang et al., 2006). Therefore, it is reasonable to expect that LAB produce specific superoxide anion radical scavengers, which can be metabolic compounds or degradation products of milk proteins derived from bacteria.

\section{Chelating effects of plain yogurt and soy yogurts upon ferrous ions}

The ferrous ion-chelating activities of plain yogurt and soy 
yogurt are depicted in Table 4. The ferrous ion-chelating ability of both plain yogurt and soy yogurt fermented with the tested strains ranged widely from $40.9 \pm 1.4 \%$ to $61.5 \pm 0.9 \%$. In case of L. casei PC05, no significant correlation was found between the ferrous ion-chelation ability and the type of yogurt. However, the chelating ability of soy yogurt fermented with $L$. acidophilus PC16 was significantly $(P<0.05)$ higher than that of plain yogurt. The values of the ferrous ion- chelation activity of plain yogurt and soy yogurt did not change significantly $(P<0.05)$ during storage. However, the ferrous ion-chelating ability of the yogurt samples was lower than that of $0.1 \mathrm{mg} / \mathrm{ml}$ EDTA (97.2\%). These results indicated that both plain yogurt and soy yogurt fermented with LAB isolated from pickled cabbage are good ferrous ion chelators, although the tested LAB showed strain-specific differences in their ability to chelate ferrous ions.

Some LAB strains, e.g., S. thermophilus 821, B. longum 15708 , and $L$. casei KCTC 3260 , were reported to possess antioxidant activity by removing metal ions that might participate in hydroxyl-radical-generating Fenton reactions. $L$. plantarum $\mathrm{C} 88, \mathrm{C} 10$, and $\mathrm{K} 25$ showed strong hydroxyl radical scavenging activity, probably due to their capability of chelating metal ions, e.g., ferrous ions (Li et al., 2012). The ferrous ion-chelating activity $(72.06 \%)$ of $L$. casei 01 could be due to chelators, which can prevent metal ions from catalyzing oxidation reactions (Kim et al., 2005). The chelation of ferrous ions by LAB strains may inhibit the generation of hydroxyl radicals. Among the metal ions, free ferrous ions are involved in catalyzing oxidation reactions, leading to the formation of ROS in the presence of transition metals such as iron and copper (Halliwell et al., 1987). Chelators reduce the concentration of free ferrous ions by forming stable iron (II) chelate complexes and, thus, decreasing ROS, which are implicated in carcinogenesis and cardiovascular diseases (Abubakr et al., 2012). Therefore, the chelation of metal ions is a very effective antioxidant action for the prevention of lipid peroxidation and protection against oxidative damage by superoxide, hydrogen peroxide, hydroxyl radicals, and hydroperoxide (Kim et al., 2005).

Several researchers have reported the ability of milk proteins (e.g., lactoferrin, serum albumin, casein, and a high molecular-weight fraction of whey) to bind ferric or ferrous ions, i.e., the presence of iron-chelating activity. Furthermore, asparagine and glutamine, which were found in milk fractions, contain phosphoserine residues and carboxyl groups that exhibit a strong affinity for iron (Zourari et al., 1992). Pena-Ramos and Xiong (2001) suggested that the chelating activity against pro-oxidative metal ions may be caused by the termination of certain radical chain reactions through specific side-chain groups of amino acid residues of antioxidant peptides. Liu et al. (2005a) reported that phenolic compounds derived from soybeans were able to chelate ferrous ions into the catalytically inactive form. Of the total milk components, the phosphoserine residues located on the surface of casein micelles, which sequester iron and copper ions, may also contribute to the antioxidant activity of milk. Moreover, Abubakr et al. (2012) suggested a direct relationship between the soluble protein or peptide concentration in skim milk and chelation capability.

\section{Reducing power of plain yogurt and soy yogurt}

The relative reducing powers of plain yogurt and soy yogurt are shown in Table 4 . The reducing power of plain yogurt and soy yogurt fermented with $L$. casei PC05 and L. acidophilus

Table 4. Changes of ferrous ion chelating and reducing power of plain yogurt and soy yogurt fermented with L. casei PC05 and L. acidophilus PC16 during cold storage

\begin{tabular}{|c|c|c|c|c|c|c|c|}
\hline \multirow{2}{*}{$\begin{array}{l}\text { Antioxidant } \\
\text { activity }\end{array}$} & \multirow{2}{*}{ Strain } & \multirow{2}{*}{ Sample } & \multicolumn{5}{|c|}{ Storage time (days) } \\
\hline & & & 0 & 2 & 4 & 6 & 8 \\
\hline \multirow{5}{*}{$\begin{array}{c}\mathrm{Fe}^{2+} \\
\text { chelating }(\%)\end{array}$} & \multirow{2}{*}{ PC05 } & Plain yogurt & $41.2 \pm 1.5^{\mathrm{c}}$ & $40.8 \pm 0.7^{\mathrm{c}}$ & $40.6 \pm 0.8^{\mathrm{c}}$ & $40.2 \pm 1.9^{\mathrm{c}}$ & $40.5 \pm 1.2^{\mathrm{c}}$ \\
\hline & & Soy yogurt & $40.9 \pm 1.4^{\mathrm{c}}$ & $40.5 \pm 1.0^{\mathrm{c}}$ & $41.6 \pm 0.8^{\mathrm{c}}$ & $41.7 \pm 0.7^{\mathrm{c}}$ & $41.6 \pm 1.0^{\mathrm{c}}$ \\
\hline & \multirow{2}{*}{ PC16 } & Plain yogurt & $56.0 \pm 1.2^{\mathrm{bAB}}$ & $59.2 \pm 1.7^{\mathrm{bA}}$ & $57.9 \pm 2.7^{\mathrm{bAB}}$ & $55.9 \pm 1.1^{\mathrm{bB}}$ & $57.6 \pm 1.6^{\mathrm{bAB}}$ \\
\hline & & Soy yogurt & $61.5 \pm 0.9^{\mathrm{a}}$ & $60.2 \pm 0.8^{\mathrm{a}}$ & $61.5 \pm 1.0^{\mathrm{a}}$ & $62.0 \pm 0.6^{\mathrm{a}}$ & $61.9 \pm 1.3^{\mathrm{a}}$ \\
\hline & \multicolumn{2}{|c|}{ EDTA } & & & $97.2 \pm 3.4$ & & \\
\hline \multirow{6}{*}{$\begin{array}{c}\text { Reducing } \\
\text { power } \\
\text { (absorbance at } \\
700 \mathrm{~nm} \text { ) }\end{array}$} & \multirow{2}{*}{ PC05 } & Plain yogurt & $0.52 \pm 0.03^{\mathrm{b}}$ & $0.53 \pm 0.20^{b}$ & $0.51 \pm 0.04^{\mathrm{c}}$ & $0.50 \pm 0.15^{\mathrm{d}}$ & $0.51 \pm 0.03^{\mathrm{c}}$ \\
\hline & & Soy yogurt & $0.61 \pm 0.02^{\mathrm{a}}$ & $0.61 \pm 0.03^{\mathrm{a}}$ & $0.65 \pm 0.06^{\mathrm{b}}$ & $0.69 \pm 0.06^{\mathrm{a}}$ & $0.60 \pm 0.10^{\mathrm{b}}$ \\
\hline & \multirow{2}{*}{$\mathrm{PC} 16$} & Plain yogurt & $0.53 \pm 0.03^{b}$ & $0.55 \pm 0.04^{b}$ & $0.55 \pm 0.04^{\mathrm{c}}$ & $0.57 \pm 0.06^{\mathrm{c}}$ & $0.55 \pm 0.05^{\mathrm{c}}$ \\
\hline & & Soy yogurt & $0.64 \pm 0.02^{\mathrm{a}}$ & $0.64 \pm 0.06^{\mathrm{a}}$ & $0.69 \pm 0.15^{\mathrm{a}}$ & $0.65 \pm 0.06^{\mathrm{b}}$ & $0.65 \pm 0.05^{\mathrm{a}}$ \\
\hline & \multirow{2}{*}{\multicolumn{2}{|c|}{$\begin{array}{c}\text { Ascorbic acid } \\
\text { BHA }\end{array}$}} & & & $0.73 \pm 0.02$ & & \\
\hline & & & & & $1.01 \pm 0.03$ & & \\
\hline
\end{tabular}

Data are means \pm SD from triplicate determinations.

${ }^{\text {a-d }}$ Values within a column with different superscripts are significantly each groups at $p<0.05$ by Duncan's multiple range test.

${ }^{\mathrm{AB}}$ Values within a row with different superscripts are significantly each groups at $p<0.05$ by Duncan's multiple range test. 
PC16 was in the range of $0.52 \pm 0.03$ to $0.64 \pm 0.02$, which was lower than those of ascorbic acid $(0.73 \pm 0.02)$ and BHA $(1.01 \pm 0.03)$. The total reducing capacity differed significantly $(P<0.05)$ depending on the yogurt sample, i.e., soy yogurt fermented with the tested strains showed greater reducing power than plain yogurt. Furthermore, there was no significant difference $(P>0.05)$ in the reducing power of the yogurt samples during cold storage. Similar to the observed free radical scavenging activity, soy yogurt fermented with the test strains demonstrated greater reducing activity than plain yogurt, suggesting that metabolites with superior reducing power might be produced during fermentation of soy yogurt.

Lin and Yen (1999) have reported that several LAB strains had relatively high reducing activity, which was suggested to be derived from actions of intracellular antioxidants and proteins. The strains L. bulgaricus LB207 and L. acidophilus LA100 exhibited the highest reducing power, because they might contain higher amounts of reductone; therefore, cells and/or compounds obtained from specific strains that have reducing power could inhibit oxidative reactions (Kim et al., 2005). The reducing power, which may serve as a significant indicator of potential antioxidant activity, refers to antioxidant enzymes such as catalase, SOD, and peroxidase or non-enzymatic compounds such as ascorbate, $\alpha$-tocopherol, and glutathione that have the ability to reduce oxygen radicals or ferrous ions (Kim et al., 2005).

Several scientists have found that the reducing power of fermented milk was significantly higher than that of unfermented milk. Furthermore, certain metabolites, e.g., glutathione, which demonstrate superior reducing power might be produced during fermentation and could possibly react with free radicals to stabilize and terminate radical chain reactions (Wu et al., 2010). Proteins and peptides contained in soybean may contribute to the increased hydrogen-donating ability and reducing activity of soymilk after fermentation (Liu et al., 2005a). Fermented soymilk might also contain reductons, leading to enhanced reducing activity during fermentation (Wang et al., 2006). On the basis of the results obtained in this study, the increase in the reducing power of soy yogurt compared to plain yogurt might be attributable to antioxidant compounds contained in soybean.

\section{SOD activity of plain yogurt and soy yogurt}

The SOD activities of plain yogurt and soy yogurt are shown in Table 5. The SOD activity of plain yogurt and soy yogurt fermented with $L$. case $i$ PC05 was $0.70 \pm 0.01 \mathrm{U} / \mathrm{ml}$ and $0.73 \pm$ $0.01 \mathrm{U} / \mathrm{ml}$, respectively. The enzyme activity of plain yogurt and soy yogurt fermented with $L$. acidophilus PC16 was $0.55 \pm$ 0.02 and $0.60 \pm 0.02 \mathrm{U} / \mathrm{ml}$, respectively. The SOD activity tended to decrease in yogurt samples after 8 days of storage at $4^{\circ} \mathrm{C}$, but the difference was not significant $(P>0.05)$. The SOD activity was significantly $(P<0.05)$ higher in yogurt samples fermented with $L$. casei PC05 compared to that in samples fermented with $L$. acidophilus PC16. This may be due to the excellent superoxide anion scavenging ability of yogurt samples fermented with $L$. casei PC05 compared to those fermented with $L$. acidophilus PC16.

SOD is responsible for the conversion of superoxide radicals to hydrogen peroxide and molecular oxygen or the prevention of the formation of radicals and the synthesis or regeneration of non-enzymatic antioxidants. Thus, SOD is an enzyme that is related to important antioxidant defense mechanism against oxidative stress in nearly all cells exposed to oxygen (Liu et al., 2005 b). It has been reported previously that by producing SOD, some LAB play a role in preventing pathological concentrations of oxygen radicals. However, the antioxidant mechanism of the bacterial strains is still unclear (Archibald and Fridovich, 1981; Han and Fioramonti, 2008). Kim et al. (2005) demonstrated that some yogurt starter cultures, i.e., $L$. casei O1, $L$. acidophilus LA100, L. rhamnosus GG744, L. acidophilus LA5, and $L$. bulgaricus LB207, showed SOD activity in the range of 6.67 to $10.66 \mathrm{U} / \mathrm{g}$ of protein. Furthermore, because the lysates of $L$. fermentum E-3 (0.859 $\pm 0.309 \mathrm{U} \mathrm{mg} /$ protein) and E-18 $(0.761 \pm 0.014 \mathrm{Umg} /$ protein $)$ were shown to have SOD activity, the L. casei PC05 and L. acidophilus PC16 might use some potent mechanisms to eliminate ROS (Kullisaar et al.,

Table 5. SOD of plain yogurt and soy yogurt fermented with L. casei PC05 and L. acidophilus PC16

\begin{tabular}{|c|c|c|c|c|}
\hline \multirow{3}{*}{ Storage time (days) } & \multicolumn{4}{|c|}{ Specific activity (U/ml) } \\
\hline & \multicolumn{2}{|c|}{$\mathrm{PC} 05$} & \multicolumn{2}{|c|}{$\mathrm{PC} 16$} \\
\hline & Plain yogurt & Soy yogurt & Plain yogurt & Soy yogurt \\
\hline 0 & $0.70 \pm 0.01^{\mathrm{B}}$ & $0.73 \pm 0.01^{\mathrm{A}}$ & $0.55 \pm 0.02^{\mathrm{D}}$ & $0.60 \pm 0.02^{\mathrm{C}}$ \\
\hline 2 & $0.69 \pm 0.03^{\mathrm{A}}$ & $0.70 \pm 0.01^{\mathrm{A}}$ & $0.54 \pm 0.01^{\mathrm{C}}$ & $0.59 \pm 0.01^{\mathrm{B}}$ \\
\hline 4 & $0.68 \pm 0.02^{\mathrm{A}}$ & $0.71 \pm 0.02^{\mathrm{A}}$ & $0.55 \pm 0.03^{\mathrm{B}}$ & $0.59 \pm 0.02^{\mathrm{B}}$ \\
\hline 6 & $0.68 \pm 0.01^{\mathrm{A}}$ & $0.72 \pm 0.03^{\mathrm{A}}$ & $0.55 \pm 0.02^{\mathrm{B}}$ & $0.58 \pm 0.01^{\mathrm{B}}$ \\
\hline 8 & $0.67 \pm 0.02^{\mathrm{B}}$ & $0.70 \pm 0.01^{\mathrm{A}}$ & $0.53 \pm 0.01^{\mathrm{D}}$ & $0.56 \pm 0.01^{\mathrm{C}}$ \\
\hline
\end{tabular}

Data are means \pm SD from triplicate determinations.

${ }^{\mathrm{A}-\mathrm{D}}$ Values within a row with different superscripts are significantly each groups at $p<0.05$ by Duncan's multiple range test. 
2002). Li et al. (2013) demonstrated that exopolysaccharide isolated from $L$. plantarum C88 increaed the activity of SOD; thus, this component exerts antioxidant effects that may involve scavenging of ROS and reducing lipid peroxidation.

Further, fermented milk and soymilk also contain SOD, which contributes to the superoxide anion scavenging activity (Liu et al., 2005a). They reported that the SOD activity in milk (5.22-5.26 U/ml) and soymilk (0.20-0.29 U/ml) did not appear to change during kefir fermentation. Ejtahed et al. (2012) noted that probiotic yogurt significantly $(P<0.05)$ increased erythrocyte SOD activity and that the consumption of yogurt improved the antioxidant status in type 2 diabetic patients.

\section{Inhibition of linoleic acid peroxidation}

As shown in Table 6, linoleic acid peroxidation was inhibited in plain yogurt and soy yogurt fermented with $L$. casei PC05 and L. acidophilus PC16. The inhibition rates of linoleic acid peroxidation ranged from $49.4 \pm 3.4 \%$ to $61.4 \pm 3.5 \%$ for plain yogurt and soy yogurt fermented with these strains, respectively. Plain yogurt and soy yogurt fermented with $L$. acidophilus PC16 inhibited lipid peroxidation by $>55 \%$, whereas plain yogurt fermented with $L$. casei PC05 exhibited the lowest level of inhibition $(49.4 \% \pm 3.4 \%)$. Yogurt samples fermented with $L$. casei PC05 and L. acidophilus PC16 exhibited higher antioxidant activity than ascorbic acid. However, the inhibition of linoleic acid peroxidation by the yogurt samples was lower than that by BHA $(97.2 \% \pm 3.4 \%)$. The degree of lipid peroxidation inhibition of these 2 yogurts did not changed during storage. These results indicated the tested strains have good antioxidant activity with regard to lipid peroxidation inhibition, even though there was a difference in the total antioxidant activity of the strains.

The process of lipid peroxidation is initiated by the attack of a free radical, generated by various products such as hydrocarbon gases, cytotoxic aldehydes, and free oxygen radicals, on fatty acids or fatty acyl side chains (Dargel, 1992). The products of lipid peroxidation are capable of causing oxidative damage to all cellular components, including lipid, proteins, nucleic acids, and carbohydrates, resulting in a decrease in the fluidity of the cell membrane, alteration of membrane properties, and disruption of membrane-bound proteins (Halliwell and Gutteridge, 1984). Therefore, the inhibition of lipid peroxidation is of great importance to prevent deterioration of food quality and protect cells in the human body against oxidative stress and disease processes that involve free radicals (Lin and Yen, 1999; Liu et al., 2005a). Antioxidant defense mechanisms may be divided into 4 categories: prevention of the formation of active oxidants; scavenging, quenching and removal of active oxidants; repair of damage and excretion of toxic oxidation products; and adaptive responses to ROS (Birben et al., 2012).

$\mathrm{LAB}$ are able to exhibit antioxidant activity in different ways; however, the mechanism by which the strains inhibit lipid oxidation and substances related to the activity have not been clearly identified (Zhang and Li, 2013). The antioxidant potential of lactobacilli has been reported in previous reports. Kim et al. (2006) reported that L. acidophilus KCTC 3111 originated from humans was able to inhibit lipid peroxidation by $49.7 \%$ in intact cells, whereas L. acidophilus KCTC 3141 showed little inhibition of peroxidation. Lin and Yen (1999) reported that in case of $L$. cremoris $\mathrm{B}$ and $L$. jensenii, the development of lipid peroxidation inhibitory activity was connected to bacterial growth. Ahotupa et al. (1996) suggested that L. rhamnosus GG inhibited lipid peroxidation in vitro due to the ferrous ion-chelating and superoxide anion scavenging ability. Moreover, the antioxidant activity of some LAB strains could also be attributed to their production of cell-surface compounds, e.g., extracellular polysaccharides, cell-surface proteins and lipoteicholic acid. The removal of cell surface compounds obtained from $L$. plantarum C88 resulted in a significant decrease in the antioxidant activity of the strain ( $\mathrm{Li}$ et al., 2012). In addition, Liu et al. (2005a) found that soymilk exhibited a more substantial inhibitory effect on linoleic acid peroxidation than milk.

Consequently, these results reveal that the antioxidant activity of plain yogurt and soy yogurt fermented with $L$. casei

Table 6. Inhibition of lipid peroxidation of plain yogurt and soy yogurt fermented with L. casei PC05 and L. acidophilus PC16

\begin{tabular}{|c|c|c|c|c|c|c|}
\hline \multirow{2}{*}{ Sample } & \multirow{2}{*}{ Strain } & \multicolumn{5}{|c|}{ Storage time (days) } \\
\hline & & 0 & 2 & 4 & 6 & 8 \\
\hline Plain yogurt & PC05 & $49.4 \pm 3.4^{\mathrm{c}}$ & $51.3 \pm 4.6^{\mathrm{b}}$ & $52.4 \pm 1.7^{b}$ & $50.5 \pm 2.5^{b}$ & $52.2 \pm 3.2^{\text {bc }}$ \\
\hline \multirow{2}{*}{ Soy yogurt } & $\mathrm{PC} 05$ & $51.4 \pm 4.5^{\mathrm{bc}}$ & $50.7 \pm 3.6^{b}$ & $52.2 \pm 2.6^{\mathrm{b}}$ & $52.7 \pm 1.4^{\mathrm{b}}$ & $50.1 \pm 3.0^{\mathrm{c}}$ \\
\hline & $\mathrm{PC} 16$ & $61.4 \pm 3.5^{\mathrm{a}}$ & $62.3 \pm 4.5^{\mathrm{a}}$ & $60.5 \pm 5.4^{\mathrm{a}}$ & $63.2 \pm 2.5^{\mathrm{a}}$ & $62.5 \pm 3.5^{\mathrm{a}}$ \\
\hline \multicolumn{2}{|c|}{ Ascorbic acid } & & & $43.2 \pm 1.8$ & & \\
\hline \multicolumn{2}{|c|}{ BHA } & & & $97.2 \pm 3.4$ & & \\
\hline
\end{tabular}

Data are means \pm SD from triplicate determinations.

${ }^{a-c}$ Values within a column with different superscripts are significantly different from each groups at $p<0.05$ by Duncan's multiple range test. 
PC05 and L. acidophilus PC16 isolated from pickled cabbage may be involved in the termination of free radical reactions, ferrous ion-chelating ability, reducing power, and SOD activity. Thus, these strains could be considered as potential candidates to be applied in functional foods and natural antioxidant supplements. In addition, these findings suggest that plain yogurt and soy yogurt fermented with these strains are promising fermented foods in terms of preventing oxidative damage. Thus, because these yogurts showed good antioxidant activity, they could be useful in the dairy manufacturing industry. In the future, further in vivo studies are needed to elucidate the antioxidant mechanisms of action of lactic starter cultures and fermented dairy foods in the human gastrointestinal tract.

\section{적 요}

양배추 피클로부터 분리된 유산균으로 발효하여 제조한 플레 인 요구르트와 소이 요구르트를 저장하는 동안 미생물학적 및 물리화학적 변화와 항산화 특성을 조사하였다. 분리 균주는 당 분해능과 유전자 염기서열 분석을 통해 L. casei PC05와 L. acidophilus PC16으로 동정되었다. Lactobacillus acidophilus $\mathrm{PC} 16$ 균주로 발효시킨 요구르트의 적정산도, 점도 및 균수는 $L$. casei PC05 균주에 의해 제조된 요구르트에 비해 높게 나타났으 며, 특히 플레인 요구르트보다 소이 요구르트에서 세균수와 물 리화학적 요인의 측정값이 유의하게 높은 것으로 확인되었다. 한편, L. acidophilus PC16 균주로 발효시킨 요구르트는 DPPH 라디칼 소거능과 철이온 킬레이팅 활성이 높았으나, L. casei PC05 균주의 요구르트는 superoxide anion 제거능과 SOD 활성 이 높은 것으로 나타났다. 대부분의 항산화능은 플레인 요구르 트보다 소이 요구르트에서 더 높게 나타났으며, 요구르트의 지 질과산화 억제능은 항산화 활성에 기인하는 것으로 추정된다. 또한 발효직후 요구르트의 미생물학적, 물리화학적 및 항산화 활성은 $4^{\circ} \mathrm{C}$ 에서 8 일간 저장하는 동안 거의 일정한 수준으로 유 지되었다.

\section{References}

Abubakr, M.A.S., Hassan, Z., Imdakim, M.A., and Sharifah, N.R.S.A. 2012. Antioxidant activity of lactic acid bacteria (LAB) fermented skim milk as determined by 1,1-diphenyl-2-picrylhydrazyl (DPPH) and ferrous chelating activity (FCA). Afr. J. Microbiol. Res. 6, 63586364.

Ahotupa, M., Saxelin, M., and Korpela, R. 1996. Antioxidative properties of Lactobacillus GG. Nutr. Today 31, 51S-52S

Archibald, F.S. and Fridovich, I. 1981. Manganese, superoxide dismutase, and oxygen tolerance in some lactic acid bacteria. $J$. Bacteriol. 146, 928-936.

Birben, E., Sahiner, U.M., Sackesen, C., Erzurum, S., and Kalayci, O. 2012. Oxidative stress and antioxidant defense. World Allergy Organ J. 5, 9-19.

Bourdichon, F., Casaregola, S., Farrokh, C., Frisvad, J.C., Gerds, M.L., Hammes, W.P., Hamett, J., Huys, G., Laulund, S., Ouwehand, A., and et al. 2012. Food fermentations: Microorganisms with technological beneficial use. Int. J. Food Microbiol. 154, 87-97.

Buchmeier, N., Bossie, S., Chen, C.Y., Fang, F.C., Guiney, D., and Libby, S. 1997. Sly A, a transcriptional regulator of Salmonella typhimurium, is required for resistance to oxidative stress and is expressed in the intracellular environment of macrophages. Infect. Immun. 65, 3725-3730.

Castro, L. and Freeman, B.A. 2001. Reactive oxygen species in human health and disease. Nutrition 17, 161-165.

Chougrani, F., Cheriguene, A., and Bensoltane, A. 2008. Use of lactic strains isolated from Algerian ewe's milk in the manufacture of a natural yogurt. Afr. J. Biotechnol. 7, 1181-1186.

Dargel, R. 1992. Lipid peroxidation - A common pathogeneticmechanism? Exp. Toxico. Pathol. 44, 169-181.

Decker, E.A. and Welch, B. 1990. Role of ferritin as a lipid oxidation catalyst in muscle food. J. Agric. Food Chem. 38, 674-677.

Ejtahed, H.S., Mohtadi-Nia, J., Homayouni-Rad, A., Niafar, M., Asghari-Jafarabadi, M., and Mofid, V. 2012. Probiotic yogurt improves antioxidant status in type 2 diabetic patients. Nutr. 28, 539-543.

Ghorbani, A., Pourahamd, R., Fallahpour, M., and Assadi, M.M. 2012. Production of probiotic soy yogurt. Annal. Biol. Res. 3, 2750-2754.

Granelli, K., Bjorck, L., and Appelqvist, L.A. 1995. The variation of superoxide dismutase (SOD) and xanthine oxidase (XO) activities in milk using an improved method to quantitate SOD activity. J. Sci. Food Agric. 67, 85-91.

Halliwell, B. and Gutteridge, J.M.C. 1984. Oxygen toxicity, oxygen radicals, transition metals and disease. Biochem. J. 219, 1-4.

Halliwell, B., Gutteridge, J.M.C., and Anoma, O. 1987. The deoxyribose method: a simple "test tube" assay for determination of rate constants for reactions of hydroxyl radicals. Anal. Biochem. 165, 215-219.

Halliwell, B., Murcia, H.A., Chirco, S., and Aruoma, O.I. 1995. Free radical and antioxidants in food an in vivo: What they do and how they work? Food Sci. Nutr. 35, 7-20.

Hamann, W.T. and Marth, E.H. 1984. Survival of Streptococcus thermophilus and Lactobacillus bulgaricus in commercial and experimental yogurts. J. Food Prot. 47, 781-786.

Han, W. and Fioramonti, J. 2008. Anti-inflammatory properties of lactic acid bacteria producing superoxide dismutase. Am. J. Physiol. Gastrointest. Liver Physiol. 294, G353.

Irkin, R. and Songun, G.E. 2012. Applications of probiotic bacteria to the vegetable pickle products. Sci. Rev. Chem. Commun. 4, 562-567.

Kim, H.S., Chae, H.S., Jeong, S.G., Ham, J.S., Im, S.K., Ahn, C.N., and Lee, J.M. 2005. Antioxidant activity of some yogurt starter cultures. J. Anim. Sci. 18, 255-258.

Kim, H.S., Chae, H.S., Jeong, S.G., Ham, J.S., Im, S.K., Ahn, C.N., and Lee, J.M. 2006. In vitro antioxidant properties of lactobacilli. $J$. Anim. Sci. 19, 262-265.

Kullisaar, T., Zilmer, M., Mikelsaar, M., Vihalemn, T., Annuk, H., Kairane, C., and Kilk, A. 2002. Two antioxidative lactobacilli strains as promising probiotics. Int. J. Food Microbiol. 72, 215-224.

Li, Z., Liu, C., Li, D., Zhao, Y., Zhang, X., Zeng, X., Yang, Z., and Li, S. 2013. Antioxidant activity of an exopolysaccharide isolated from Lactobacillus plantarum C88. Int. J. Biol. Macromol. 54, 270-275.

Li, S., Zhao, Y., Zhang, L., Zhang, X., Huang, L., Li, D., Niu, C., Yang, Z., and Wang, Q. 2012. Antioxidant activity of Lactobacillus plantarum strains isolated from traditional Chinese fermented foods. Food Chem. 135, 1914-1919.

Lin, M.Y. and Yen, C.L. 1999. Inhibition of lipid peroxidation by Lactobacillus acidophilus and Bifidobacterium longum. J. Agric. Food Chem. 47, 3661-3664. 
Liu, J.R., Chen, M.J., and Lin, C.W. 2005a. Antimutagenic and antioxidant properties of milk-kefir and soymilk-kefir. J. Agric. Food Chem. 53, 2467-2474.

Liu, J.R., Lin, Y.Y., Chen, M.J., Chen, L.J., and Lin, C.W. 2005 b. Antioxidative activities of kefir. Asian-Aust. J. Anim. Sci. 18, 567-573.

Lourens-Hattingh, A. and Viljoen, B.C. 2001. Yogurt as probiotic carrier food. Int. Dairy J. 11, 1-17.

Mital, B.K. and Steinkraus, K.H. 1974. Growth of lactic acid bacteria in soy milk. J. Food Sci. 39, 1018-1022.

Nishikimi, M., Rao, N.A., and Yagi, K. 1972. The occurrence of superoxide anion in the reaction of reduced phenzaine methosulfate and molecular oxygen. Biochem. Biophy. Res. Co. 46, 849-853.

Nishino, T., Shibahara-Sone, H., Kikuchi-Hayakawa, H., and Ishikawa, F. 2000. Transit of radical scavenging activity of milk products prepared by Maillard reaction and Lactobacillus casei strains Shirota fermentation through the hamster intestine. J. Dairy Sci. 83, 915-922.

Noni, I.D., Pellegrino, L., and Masotti, F. 2004. Survey of selected chemical and microbiological characteristics of (plain or sweetened) natural yogurts from the Italian market. Lait 84, 421-433.

Osawa, T. and Namiki, M.A. 1981. A novel type of antioxidant isolated from leaf wax of eucalyptus leaves. Agric. Biol. Chem. 45, 735-739.

Ouwehand, A.C. and Salminen, S.J. 1998. The health effects of cultured milk products with viable and non-viable bacteria. Int. Dairy J. 8, 749-758.

Oyaizu, M. 1986. Studies on products of browning reaction antioxidative activities of products of browning reaction prepared from glucose-amine. Jpn. J. Nutr. 44, 307-315.

Pena-Ramos, E.A. and Xiong, Y.L. 2001. Antioxidative activity of whey protein hydrolysates in a liposomal system. J. Dairy Sci. 84, 2577-2583.

Peres, C.M., Peres, C., Hemandez-Mendoza, A., and Malcata, F.X. 2012. Review on fermented plant materials as carriers and sources of potentially probiotic lactic acid bacteria-With an emphasis on table olives. Trends Food Sci. Tech. 26, 31-42.

Rawson, H.L. and Marshall, V.M. 1997. Effect of 'ropy' strains of Lactobacillus delbrueckii ssp. bulgaricus and Streptococcus thermophilus on rheology of stirred yogurt. Int. J. Food Sci. Technol. 32, 213-220.

Rivera-Espinoza, Y. and Gallardo-Navarro, Y. 2010. Non-dairy probiotic products. Food Microbiol. 27, 1-10.

Shimada, K., Fujikawa, K., Yahara, K., and Nakamura, T. 1992. Antioxidative properties of xanthan of the autoxidation of soybean oil in cyclodextrin emulsion. J. Agric. Food Chem. 40, 945-948.

Sirirat, D. and Jelena, P. 2010. Bacterial inhibition and antioxidant activity of kefir produced from Thai Jasmine rice milk. Biotechnol. 9, 332-337.

Sokolinska, D.C., Michalski, M.M., and Pikul, J. 2004. Role of the proportion of yogurt bacterial strains in milk souring and the formation of curd qualitative characteristics. Bull. Vet. Inst. Pulawy. 48, 437-441.

Songisepp, E., Kals, J., Kullisaar, T., Mandar, R., Hutt, P., and Zilmer, M. 2005. Evaluation of the functional efficacy of an antioxidative probiotic in healthy volunteers. Nutr. J. 4, 22-32.

Trachoo, N. 2002. Yogurt: The fermented milk. J. Sci. Technol. 24, 727-737.

Vij, S., Hati, S., and Yadav, D. 2011. Biofunctionality of probiotic soy yogurt. Food Nutr. Sci. 2, 502-509.

Virtanen, T., Pihlanto, A., Akkanen, S., and Korhonen, H. 2007. Development of antioxidant activity in milk whey during fermentation with lactic acid bacteria. J. Appl. Microbiol. 102, 106-115.

Wang, Y.C., Yu, R.C., and Chou, C.C. 2002. Growth and survival of bifidobacteria and lactic acid bacteria during the fermentation and storage of cultured soymilk drink. Food Microbiol. 19, 501-508.

Wang, Y.C., Yu, R.C., and Chou, C.C. 2006. Antioxidantive activities of soymilk fermented with lactic acid bacteria and bifidobacteria. Food Microbiol. 23, 128-135.

Wu, S.C., Wang, F.J., and Pan, C.L. 2010. The comparison of antioxidative properties of seaweed oligosaccharides fermented by two lactic acid bacteria. J. Mar. Sci. Technol. 18, 537-545.

Yang, J.H., Mau, J.L., Ko, P.T., and Huang, L.C. 2000. Antioxidant properties of fermented soybean broth. Food Chem. 71, 249-254.

Zhang, Y. and Li, Y. 2013. Engineering the antioxidative properties of lactic acid bacterial for improving its robustness. Curr. Opin. Biotechnol. 24, 142-147.

Zhang, S., Liu, L., Su, Y., Li, H., Sun, Q., Liang, X., and Lv, J. 2011. Antioxidative activity of lactic acid bacteria in yogurt. Afr. $J$. Microbiol. Res. 5, 5194-5201.

Zourari, A., Accolas, J.P., and Desmazeaud, M.J. 1992. Metabolism and biochemical characteristics of yogurt bacteria. A review. Lait 72, 1-34. 